\title{
Point source pollution and climate change impact from sequential batch reactor wastewater treatment plant
}

\author{
Taşeli B.K.* \\ Giresun University, Faculty of Engineering, Environmental Engineering Department, \\ 28200 Giresun/TURKEY, \\ Received: 26/12/2017, Accepted: 12/10/2017, Available online: 04/12/2017 \\ ${ }^{*}$ to whom all correspondence should be addressed: e-mail: basak.taseli@giresun.edu.tr
}

\begin{abstract}
Since sequential batch reactor (SBR) system is sequentially removes carbon, nitrogen and phosphorous in a single reactor by maintaining anoxic and aerobic stages, it recently has attracted a great deal of interest. This study evaluates the impact of wastewater treatment plant (WWTP) with a SBR system on a creek which is the influent tributary to Aegean Sea. Accordingly, this study demonstrates (1) the treatment efficiency of full-scale WWTP; (2) how WWTP influences creek's water quality from 2012 to 2015; (3) how creek influences receiving body's water quality; and (4) the potential climate change impact of a SBR treatment system. The study shows that SBR treatment plant complies with standards set by Turkish Legislations with 4-year average of $62 \%$ SS, $71 \% \mathrm{BOD}, 62 \%$ COD, $32 \%$ TN and $31 \%$ TP removal but the accumulation of pollutants occurs during low flows when point source is dominant. This is the case in the downstream of treated WWTP discharge point. The potential impact of treatment plant on climate change was calculated in terms of greenhouse gas emissions (GHG). The annual methane emissions from SBR alternated from minimum of 68.71 to maximum 248.99 tCO 2 e. Total emissions $\left(\mathrm{CH}_{4}, \mathrm{~N}_{2} \mathrm{O}\right.$ and emission due to electricity usage) from a full-scale SBR were calculated as $144.22 \mathrm{tCO}_{2} \mathrm{e}, 318.34 \mathrm{tCO}_{2} \mathrm{e}, 474.79$ $\mathrm{tCO}_{2} \mathrm{e}$ and $996.62 \mathrm{tCO}_{2} \mathrm{e}$ from 2012 to 2015, respectively.
\end{abstract}

Keywords: wastewater treatment, point source, sequential batch reactor, receiving body, greenhouse gas, emissions.

\section{Introduction}

Since SBR (Sequential Batch Reactor) system is sequentially removes carbon, nitrogen and phosphorous in a single reactor by maintaining anoxic and aerobic stages, it recently has attracted a great deal of interest. The WWTP in question operated with SBR in which all the reactions and separation takes place in one tank and in a welldefined and continuously repeated time sequence. SBR process used in this plant for high nitrogen and phosphorus removal achieved by a combination of aerobic tank, anoxic tank (fill, react, settle, draw and idle). Denitrification occurs at the beginning of the fill step taking usually $25 \%$ of the total cycling time where raw wastewater is added to the reactor. The step taking up $35 \%$ of the total cycle time is called react step where the reactions were finalized. The main purpose of third step (settle) is to allow solids separation and provide a supernatant ready to be discharged as effluent. The purpose of fourth step (draw step) ranging from 5 to $30 \%$ of the total cycle time is to remove clarified treated water from the reactor. The purpose of last step "idle" is to provide time for one reactor to complete its fill cycle before switching to another unit.

The greenhouse effect of major greenhouse gases, carbon dioxide $\left(\mathrm{CO}_{2}\right)$, methane $\left(\mathrm{CH}_{4}\right)$ and nitrous oxide $\left(\mathrm{N}_{2} \mathrm{O}\right)$ all produced in wastewater treatment operations is weighted by their Global Warming Potentials (GWP). Over a period of 100 years one ton of methane and nitrous oxide will have a warming effect equivalent to 25 and 298 ton of $\mathrm{CO}_{2}$, respectively (IPCC, 2006). In the same direction, Ravishankara et al., (2009) stated that nitrous oxide $\left(\mathrm{N}_{2} \mathrm{O}\right)$ is a significant greenhouse gas with a lifetime of 114 years with a 298-fold stronger effect of global warming than carbon dioxide and is responsible for also ozone depletion in the stratosphere. In SBR processes, ammonium is transformed into $\mathrm{N}_{2}$ gas via nitrification and denitrification. $\mathrm{N}_{2} \mathrm{O}$ is generated as a by-product or an intermediate due to insufficient oxygen during nitrification in the aeration step and due to insufficient carbon during denitrification in settling and decanting steps (Itokawa et al., 2001). Law et al., (2012) stated that wastewater treatment facilities are anthropogenic sources of $\mathrm{N}_{2} \mathrm{O}$ to the atmosphere, taking account of $3.2-10 \%$ of the total emission. In this paper, only methane and nitrous oxide are calculated since carbon that present in wastewater is biogenic and it is assumed that it is returning the carbon to the atmosphere as $\mathrm{CO}_{2}$ represents no net flux to the system (IPCC, 2006).

Wang et al., (2011) reported that based on field measurements the maximum methane flux was occurred in sludge screw conveyor with $823 \mathrm{~g} / \mathrm{m}^{2} / \mathrm{d}$ and $\mathrm{CH}_{4}$ emission occurred in every processing unit. Bousquet et al., (2006) stated that management and treatment of domestic and industrial wastewater have been identified as an important source of $\mathrm{CH}_{4}$. Methane is produced by methanogens due to low $\mathrm{O}_{2}$ and nitrate/nitrite concentration during the anaerobic and anoxic processes. In the same direction, IPPC, (2007) reported that more than 
$50 \%$ of global methane emissions are related to humanrelated activities like landfill, wastewater treatment, agriculture and certain industrial process.

It is thought that this paper will make a significant contribution to the literature at least will fill space on the wastewater treatment plant's effect on climate change. This study demonstrates 1 ) the treatment efficiency of fullscale WWTP; (2) how WWTP influences creek's water quality from 2012 to 2015; (3) how creek influences receiving body's water quality and (4) the potential climate change impact of a SBR treatment system treating domestic wastewater by calculating its GHG emissions.

\section{Materials and methods}

Table 1. Standard methods, equipments and method of measurement used in analysis

\begin{tabular}{cccc}
\hline Param. & Equipment & Standard Method & Method \\
\hline DO & Portable HACH Sension156 & TS 5677 EN 25814-1996 & Electrochemical \\
\hline $\mathrm{pH}$ & Portable HACH Sension156 & TS 3263 ISO 10523-1999 & Electrochemical \\
\hline Temp. & Portable HACH Sension156 & TS 3263 ISO 10523-1999 & Electrochemical \\
\hline EC & Portable HACH Sension156 & TS 5677 EN 25814-1996 & Electrochemical \\
\hline TP & DRLANGE-XION500 spectrophotometer & $\begin{array}{c}\text { TS ISO 8466-1:1997TS } \\
\text { EN ISO 10304-2:1997 }\end{array}$ & Spectrophotometric \\
\hline TN & DRLANGE-XION500 spectrophotometer & $\begin{array}{c}\text { TS ISO 8466-1:1997T } \\
\text { TS ISO 8466-1:1997 }\end{array}$ & Spectrophotometric \\
\hline COD & DRLANGE-XION500 spectrophotometer & $\begin{array}{c}\text { TS 2789 ISO 6060:2000 } \\
\text { TS 7094 EN 872:1999 }\end{array}$ & Spectrophotometric \\
\hline BOD & HACH- BODTrak TM II & APHA, AWWA, WEF & Respirometric \\
\hline SS & SARTORIUS vacuum filter & TS 7094 EN 872:1999 & Membrane Filtration \\
\hline TC, FC, & SARTORIUS vacuum filter & TS EN ISO 9308-1: 2004 & Membrane Filtration \\
\hline FS & S &
\end{tabular}

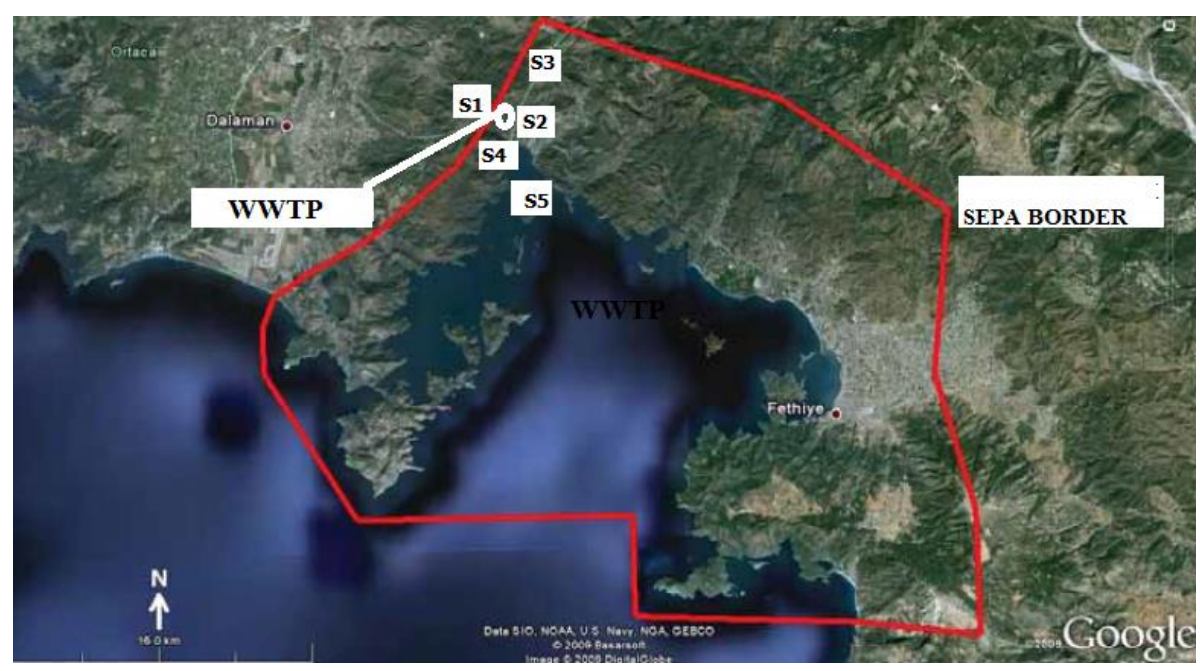

Figure 1. Study area and sampling points

\subsection{Methane $\left(\mathrm{CH}_{4}\right)$ emission calculating principles}

Estimation of organically degradable material in domestic wastewater, estimation of methane emission factor for domestic wastewater and estimation of $\mathrm{CH}_{4}$ emissions from domestic wastewater are steps for calculating $\mathrm{CH}_{4}$ emissions.

\subsection{Sampling points and chemical analysis}

A four-year data set is used to evaluate the efficiency and effect of full-scale SBR WWTP on receiving body's water quality. Monthly water samples taken from (see Fig. 1) inlet (sampling station 1, S1) and outlet (sampling station 2, S2) of the treatment plant, upstream of discharge point (sampling station 3, S3), downstream of discharge point (sampling station 4, S4) and the point where creek flows into the sea (sampling station 5, S5) were covered to prevent exposure to direct sunlight, stored in ice and then analyzed in the laboratory within 24 hours. Standard methods, equipment and method of measurement used in analysis are presented in Table 1. 
the $B_{\circ}$ value to be $0.6 \mathrm{~kg} \mathrm{CH} \mathrm{CH}_{4} / \mathrm{kg} \mathrm{BOD}$ removal and the uncertainty range to be $\pm 30 \%$. The MCF indicates that the extent to which the $\mathrm{CH}_{4}$ producing capacity (Bo) is realized in each type of treatment and discharge pathway and system taken as 0.05 (Eqn 1: Eqn 6.2 of IPCC, 2006: $\mathrm{CH} 4$ emission factor for each domestic wastewater treatment/discharge pathway or system).
TOW (total organics in wastewater in inventory year, $\mathrm{kg}$ $\mathrm{BOD} / \mathrm{yr}$ ) is a function of human population and BOD generation per person and it is expressed in terms of biochemical oxygen demand (kg BOD/year). TOW was calculated by using Equation 2 (Eqn 2: Eqn 6.3 of IPCC, 2006: Total organically degradable material in domestic wastewater).
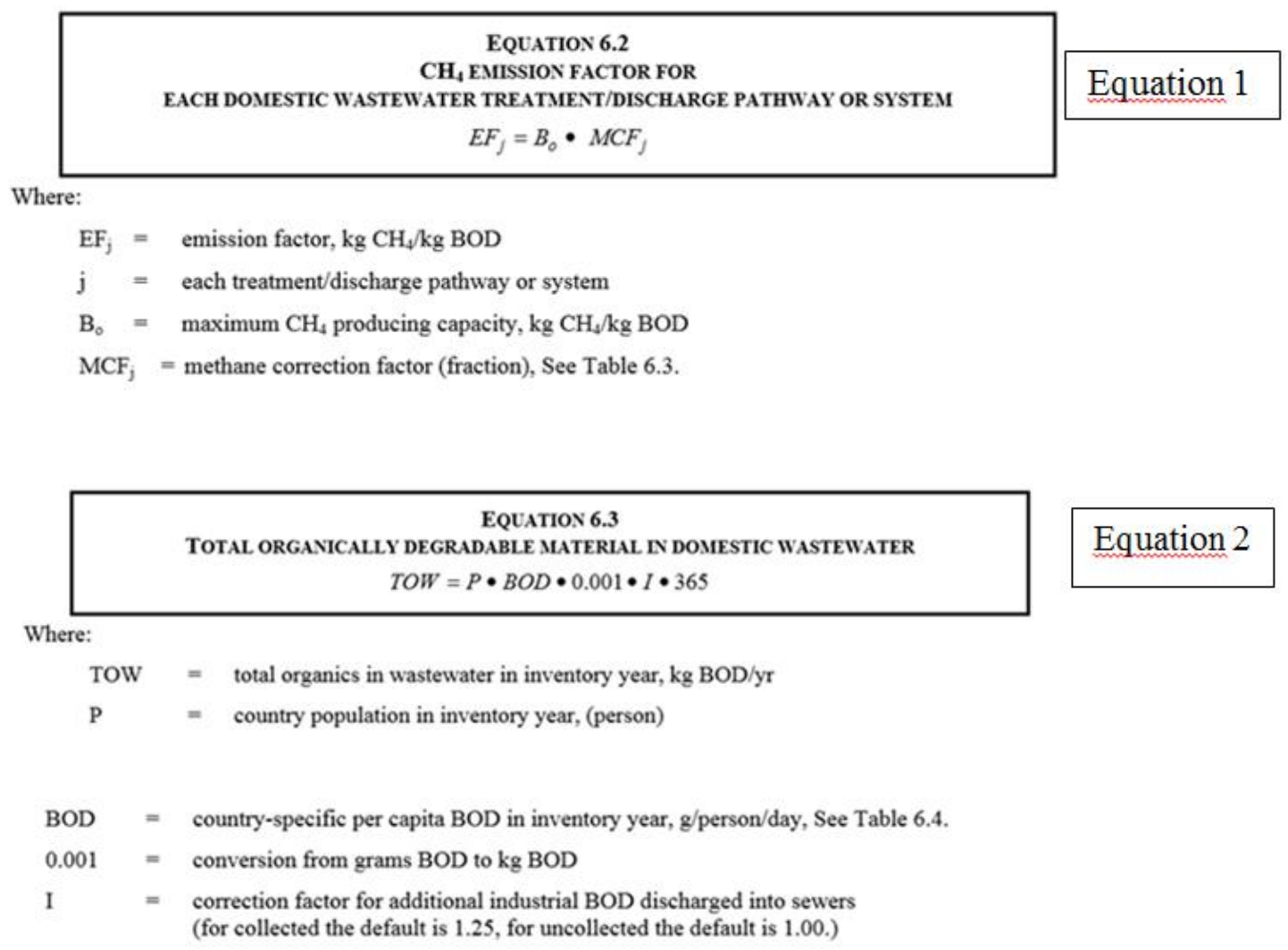

\section{Equation 2}

The general equation for estimating $\mathrm{CH}_{4}$ emissions from domestic wastewater was calculated by using equation 3 .

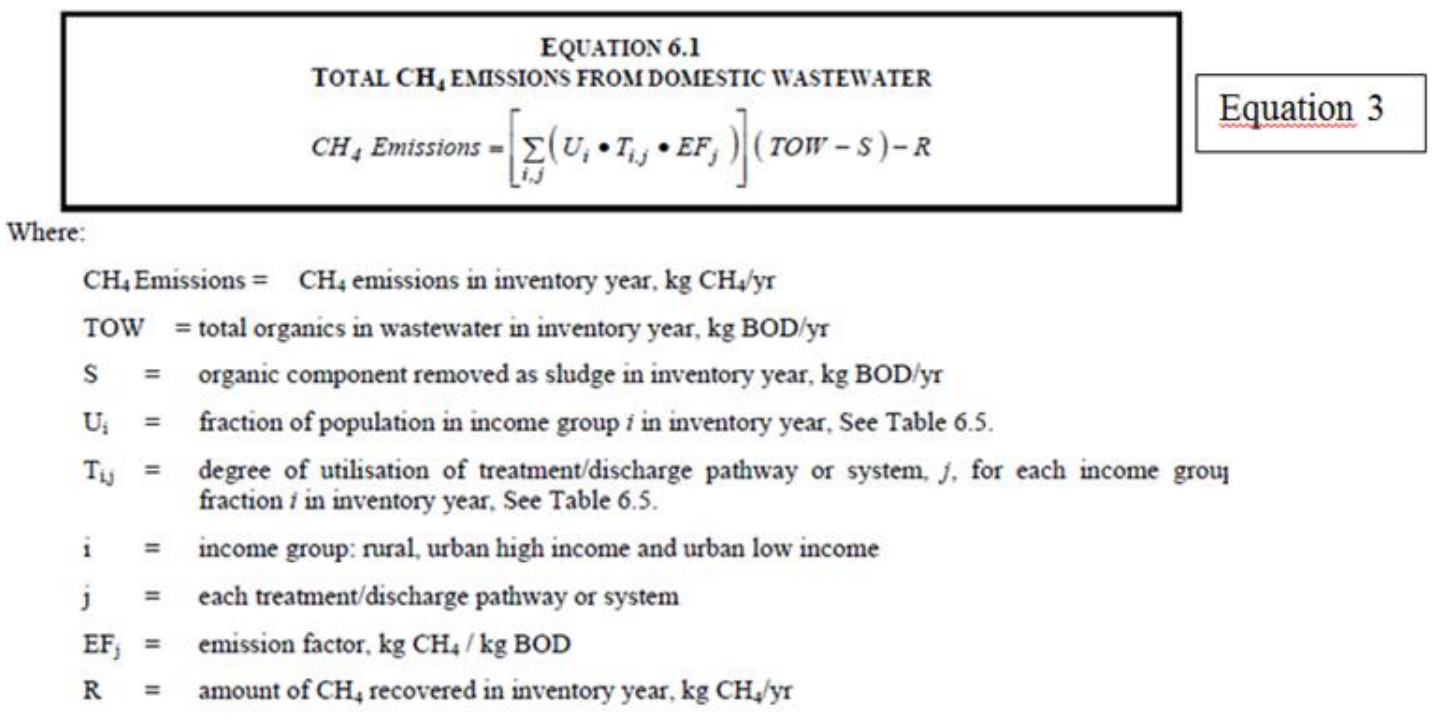

\subsection{Nitrous oxide $\left(\mathrm{N}_{2} \mathrm{O}\right)$ emission calculating principles}

Estimation of nitrogen in effluent, and estimation of emission factor and emissions of indirect $\mathrm{N}_{2} \mathrm{O}$ emissions from wastewater are steps for calculating $\mathrm{N}_{2} \mathrm{O}$ emissions. It is associated with the microbial conversion of nitrogen compound in the wastewater. It occurs as emissions from treatment plants or from wastewater after disposal of effluent into waterways, lakes or the sea. The emission factor (0.005) is taken for domestic wastewater nitrogen effluent, referring to the default value recommended by IPCC (2006). The factor $44 / 28$ is the conversion of $\mathrm{kg} \mathrm{N}_{2} \mathrm{O}-$ $\mathrm{N}$ into $\mathrm{kg} \mathrm{N} \mathrm{N}_{2} \mathrm{O}$. A simplified equation is given in Equation 5. Emission factors of $\mathrm{N}_{2} \mathrm{O}$ were evaluated by incorporating $\mathrm{N}$ loads in influent of the SBR WWTP. 


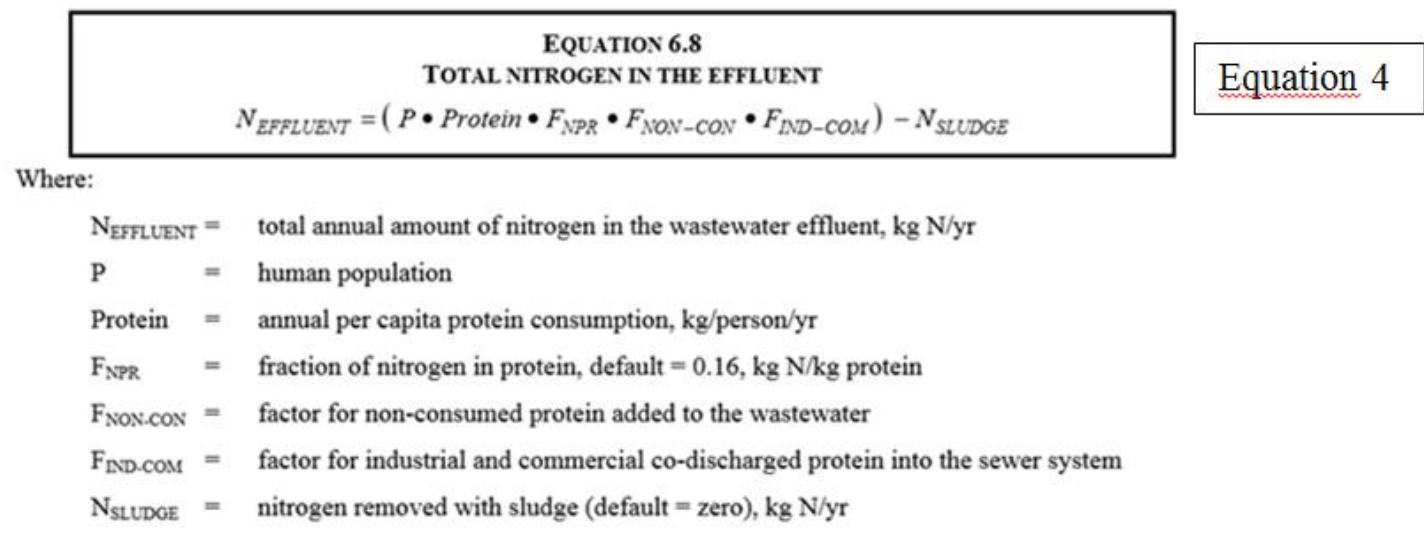

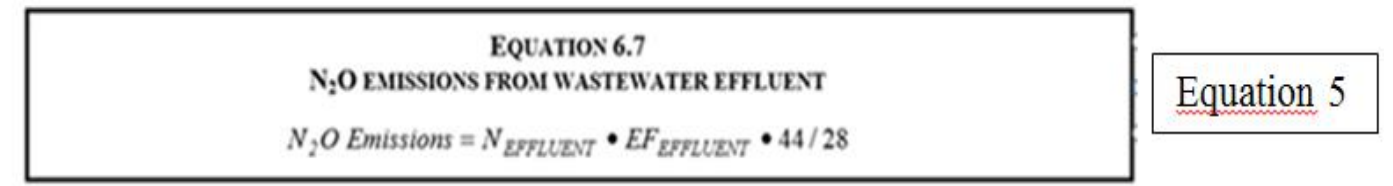

Where:

$$
\begin{aligned}
& \mathrm{N}_{2} \mathrm{O} \text { emissions }=\mathrm{N}_{2} \mathrm{O} \text { emissions in inventory year, } \mathrm{kg} \mathrm{N}_{2} \mathrm{O} / \mathrm{yr} \\
& \mathrm{N}_{\text {EmLENT }}=\text { nitrogen in the effluent discharged to aquatic environments, } \mathrm{kg} \mathrm{N} / \mathrm{yr} \\
& \mathrm{EF}_{\text {שmuEvT }}=\text { emission factor for } \mathrm{N}_{2} \mathrm{O} \text { emissions from discharged to wastewater, } \mathrm{kg} \mathrm{N} 2 \mathrm{O} \cdot \mathrm{N} / \mathrm{kg} \mathrm{N}
\end{aligned}
$$

The factor $44 / 28$ is the conversion of $\mathrm{kg} \mathrm{N}_{2} \mathrm{O} \cdot \mathrm{N}$ into kg N $\mathrm{N}_{2} \mathrm{O}$.

\subsection{Carbon dioxide $\left(\mathrm{CO}_{2}\right)$ emission calculating principles}

Two main factors causing $\mathrm{CO}_{2}$ production from wastewater treatment plants are type treatment process and electricity consumption. During anaerobic process the $\mathrm{BOD}_{5}$ of wastewater is either incorporated into biomass or it is converted to $\mathrm{CO}_{2}$ and $\mathrm{CH}_{4}$. A fraction of biomass is further converted to $\mathrm{CO}_{2}$ and $\mathrm{CH}_{4}$ via endogenous respiration. Other emission sources of carbon dioxide are sludge digesters and from digester gas combustion. In the aerobic process $\mathrm{CO}_{2}$ is produced through the breakdown of organic matter in the activated sludge process and some through the primary clarifiers. $\mathrm{CO}_{2}$ emissions from WWTP are not considered in the IPCC Guidelines because these are of biogenic origin and should not be included in national total emissions. Biogenic to origin means short cycle or natural sources of atmospheric $\mathrm{CO}_{2}$ which cycles from plants to animals to humans as part of the natural carbon cycle and food chain do not contribute to global warming. Photosynthesis produced short-cycle $\mathrm{CO}_{2}$, removes an equal mass of $\mathrm{CO}_{2}$ from the atmosphere that returns during respiration or wastewater treatment.

\subsection{Indirect GHG emissions from electricity production}

Indirect GHG emissions were calculated by multiplying total MWh used annually and emission factor 0.91 $\mathrm{tCO}_{2} \mathrm{e} / \mathrm{MW}$ (IPCC, 2006). I have followed IPCC Guidelines for National Greenhouse Gas Inventories, 2006 for calculating GHG emissions from 2012 to 2015 from SBR WWTP.

\section{Results and discussion}

3.1 Wastewater treatment efficacy of full-scale SBR wastewater treatment plant
A four-year data set (EPASA 2012, 2013, 2014 and 2015) were examined to investigate the present status of and the monthly and yearly (2012-2015) changes in, the efficiency of WWTP and its effect on receiving body. COD and BOD are the most important parameters for monitoring studies and control of waste water treatment plants. In Turkey as Urban Wastewater Treatment Directive (UWWTD, 2006) states, acceptable wastewater treatment plant effluent BOD and COD concentration is $25 \mathrm{mg} / \mathrm{l}$ and $125 \mathrm{mg} / \mathrm{l}$, respectively. Figure 2 reveals that the WWTP's effluent $B O D$ and $C O D$ values are in accordance with the Turkish UWWTD (2006). As can be seen from Figure 2 both effluent TN and TP concentrations are complying with the standards set by Turkish UWWTD. These results indicate that WWTP in question operated with $62 \% \mathrm{SS}, 71 \% \mathrm{BOD}, 62 \% \mathrm{COD}, 32$ $\%$ TN and $31 \%$ TP removal.

3.2 Impact of full-scale SBR wastewater treatment plant discharge on the primary receiving body (creek)

In order to investigate the effect of plant discharge on the receiving body's water quality, water quality classes are compared in the downstream and upstream of discharge point. The water quality of creeks in the Turkish Water Pollution Control Regulation (TWPCR, 2004) has four primary designations (Class I-IV).

Table 2 gives annual variations in the physico-chemical and bacteriological parameters at downstream (S3) and upstream (S4) discharge point of WWTP. It is clear from table that creek in which effluent discharged was dry in 2012, 2013, 2014 and the stream flow was detected only in 2015. The creek was in Class I designation for all years in terms of $\mathrm{pH}$ parameter. 
Table 2. Annual variations in the physico-chemical and bacteriological parameters

\begin{tabular}{|c|c|c|c|c|}
\hline Parameter & Year & S3 & S4 & Water quality class \\
\hline \multirow{4}{*}{$\mathrm{pH}$} & 2012 & DRY & 8 & I (high quality water) \\
\hline & 2013 & DRY & 7.92 & 1 \\
\hline & 2014 & DRY & 7.77 & $\mathrm{I}$ \\
\hline & 2015 & 8.1 & 6.95 & 1 \\
\hline \multirow{4}{*}{ Temp. $\left({ }^{\circ} \mathrm{C}\right)$} & 2012 & DRY & 24.8 & II (minimally polluted water) \\
\hline & 2013 & DRY & 23 & II \\
\hline & 2014 & DRY & 23.87 & II \\
\hline & 2015 & 23 & 21.5 & II \\
\hline \multirow{4}{*}{$\mathrm{DO}\left(\mathrm{mg} \mathrm{L}^{-1}\right)$} & 2012 & DRY & 4.4 & III (polluted water) \\
\hline & 2013 & DRY & 5.5 & III \\
\hline & 2014 & DRY & 6.7 & II \\
\hline & 2015 & 8.39 & 6.5 & II \\
\hline \multirow{4}{*}{$\operatorname{COD}\left(\mathrm{mg} \mathrm{L}^{-1}\right)$} & 2012 & DRY & 20.1 & 1 \\
\hline & 2013 & DRY & 61 & III \\
\hline & 2014 & DRY & 59.5 & III \\
\hline & 2015 & 30.48 & 42.85 & II \\
\hline \multirow{4}{*}{$\mathrm{TP}\left(\mathrm{mg} \mathrm{L}^{-1}\right)$} & 2012 & DRY & 1.3 & IV (highly polluted water) \\
\hline & 2013 & DRY & 1.07 & IV \\
\hline & 2014 & DRY & 0.21 & III \\
\hline & 2015 & 0.17 & 0.25 & III \\
\hline \multirow{4}{*}{$\begin{array}{l}\text { Total Coliforms } \\
\text { (CFU } 100 \mathrm{~mL}^{1} \text { ) }\end{array}$} & 2012 & DRY & 2356 & II \\
\hline & 2013 & DRY & 3033 & II \\
\hline & 2014 & DRY & 151000 & III \\
\hline & 2015 & 55000 & 175555 & III \\
\hline \multirow{4}{*}{$\begin{array}{l}\text { Fecal Coliforms } \\
\text { (CFU } 100 \mathrm{~mL}^{-1} \text { ) }\end{array}$} & 2012 & DRY & 891 & II \\
\hline & 2013 & DRY & 188 & II \\
\hline & 2014 & DRY & 81800 & IV \\
\hline & 2015 & 24000 & 72555 & IV \\
\hline
\end{tabular}

As Table 2 reveals in 2015 at the upstream discharge point $\mathrm{pH}$ was 8.1 whereas it drastically decreased to 6.95 in the downstream of discharge point showing the adverse effect of the wastewater treatment plant effluent. The DO concentrations in unpolluted waters (Class I) is $>8 \mathrm{mg} \mathrm{l}^{-1}$ and Class II are typically in the range of 6 to $8 \mathrm{mg} \mathrm{l}^{-1}$ and Class III is between 3-6 $\mathrm{mg} \mathrm{l}^{-1}$ (TWPCR, 2004). Primary receiving body, a creek, was in Class II designation for all years in terms of DO parameter which is an essential element for almost all aquatic life. The creek's water quality in terms of DO was Class IV in 2012 and 2013 whereas its water quality increased to Class III in 2014 and 2015. In 2015 at the upstream discharge point DO was 8.39 $\mathrm{mg} \mathrm{l}^{-1}$ whereas it drastically decreased to $6.5 \mathrm{mg} \mathrm{l}^{-1}$ showing the adverse effect of the wastewater treatment plant discharge. In addition, SS and COD concentration increased from 2.6 to $7.76 \mathrm{mg} \mathrm{l}^{-1}$, and 30.48 to $42.85 \mathrm{mg} \mathrm{l}^{-1}$ both indicating Class III water quality and both indicating the effect of WWTP effluent discharge. In 2015, TN increased from 0.21 to $3.28 \mathrm{mg} \mathrm{l}^{-1}$ in the downstream of discharge point and this high nitrate levels in waste effluents will contribute to the nutrient load of receiving waters and will enhance eutrophication effects. The creek's water quality in terms of TP designated as Class IV in 2012 and 2013 and Class III in 2014 and 2015. Phosphates are undesirable anions in receiving waters and act as the most important growth-limiting factor in eutrophication and result in a variety of adverse ecological effects. Yearly average number total coliforms ranged from 55,000 to 175,555 (CFU 100 $\mathrm{ml}^{-1}$ ) in 2015 designated as Class III water quality in downstream of discharge point. The number fecal coliforms ranged from 24,000 to 72,555 (CFU $100 \mathrm{ml}^{-1}$ ) indicating Class IV water quality in downstream of discharge point.

3.3 Water quality of ultimate receiving body the point where creek flows into the sea

It is clear that although WWTP efficiently treats domestic wastewater, it still has adverse effect on creek and this is even worse when there is no flow in creek. Another question is how creek effects receiving bodies' water quality.

The water quality of sea is investigated in terms of $\mathrm{pH}$, transparency, temperature, saturated oxygen concentration, total phenol concentration, ammonia concentration, total coliform, fecal coliforms and fecal streptococci at the point where a creek flows into the sea (S5). Receiving body was in accordance with the standards given by Bathing Water Quality Regulation BWQR, (2004) in terms of $\mathrm{pH}$, temperature, phenol concentration and ammonia concentration. Saturation oxygen values ranged from 78 to $97 \%$ in 2012 to 2015 . Transparency is well under the limit of $2 \mathrm{~m}(0.8 \mathrm{~m}$. in 2012, 1.5m. in 2014 and $0.3 \mathrm{~m}$. in 2015) probably due to high SS carried by a creek to the 
ultimate receiving body. The high values of biological parameters in 2012-2015 are believed to be lack of disinfection unit, but now plant has UV disinfection system.

3.4 Estimated wastewater treatment plant methane $\left(\mathrm{CH}_{4}\right)$ emissions

Organically degradable material in domestic wastewater was calculated by IPCC guidelines (Table 6.2 of IPCC, (2006):
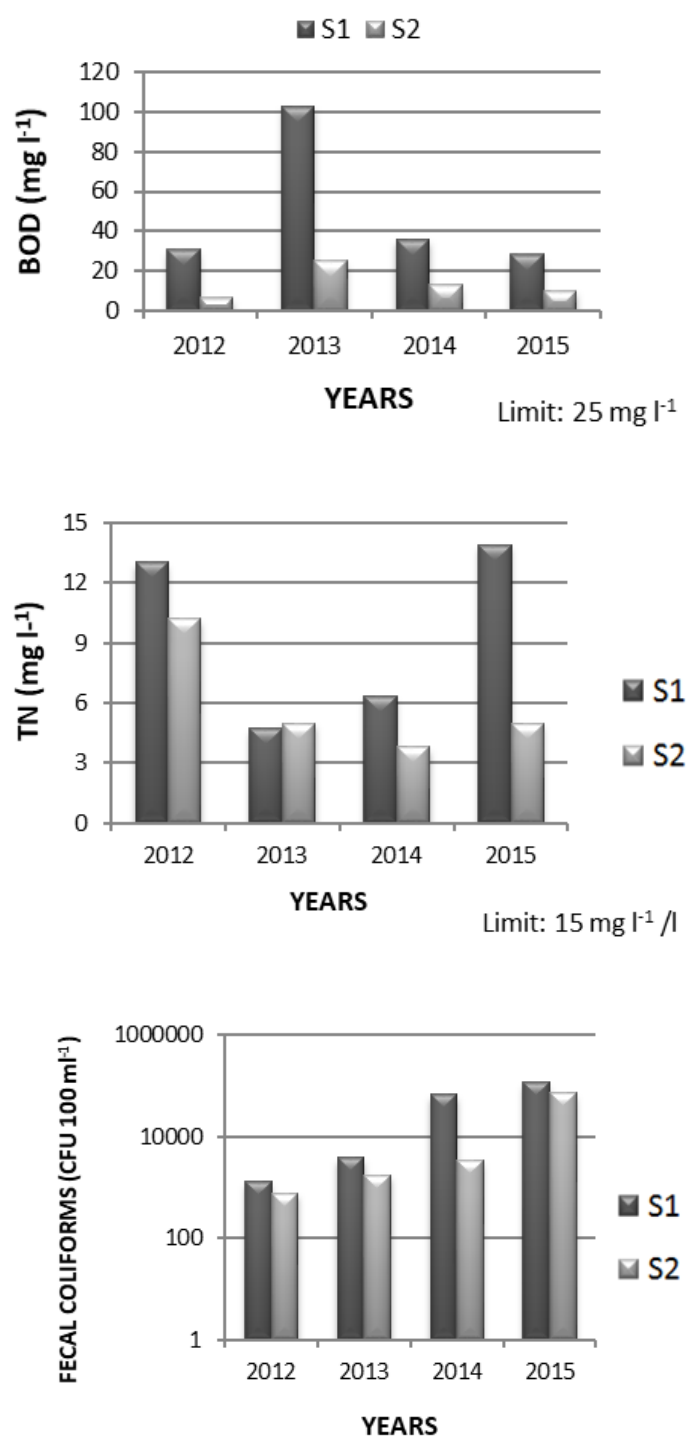

Default max. $\mathrm{CH}_{4}$ producing capacity $\left(\mathrm{B}_{0}\right)$ for domestic wastewater of) and estimated emissions from domestic wastewater was calculated by using Table 6.5 of IPCC, (2006): Suggested values for urbanization and degree of utilization of treatment discharge pathway or method $\left(\mathrm{T}_{\mathrm{i}, \mathrm{j}}\right)$ for each income group for selected countries. Table 3 gives calculated methane emissions from domestic wastewater.
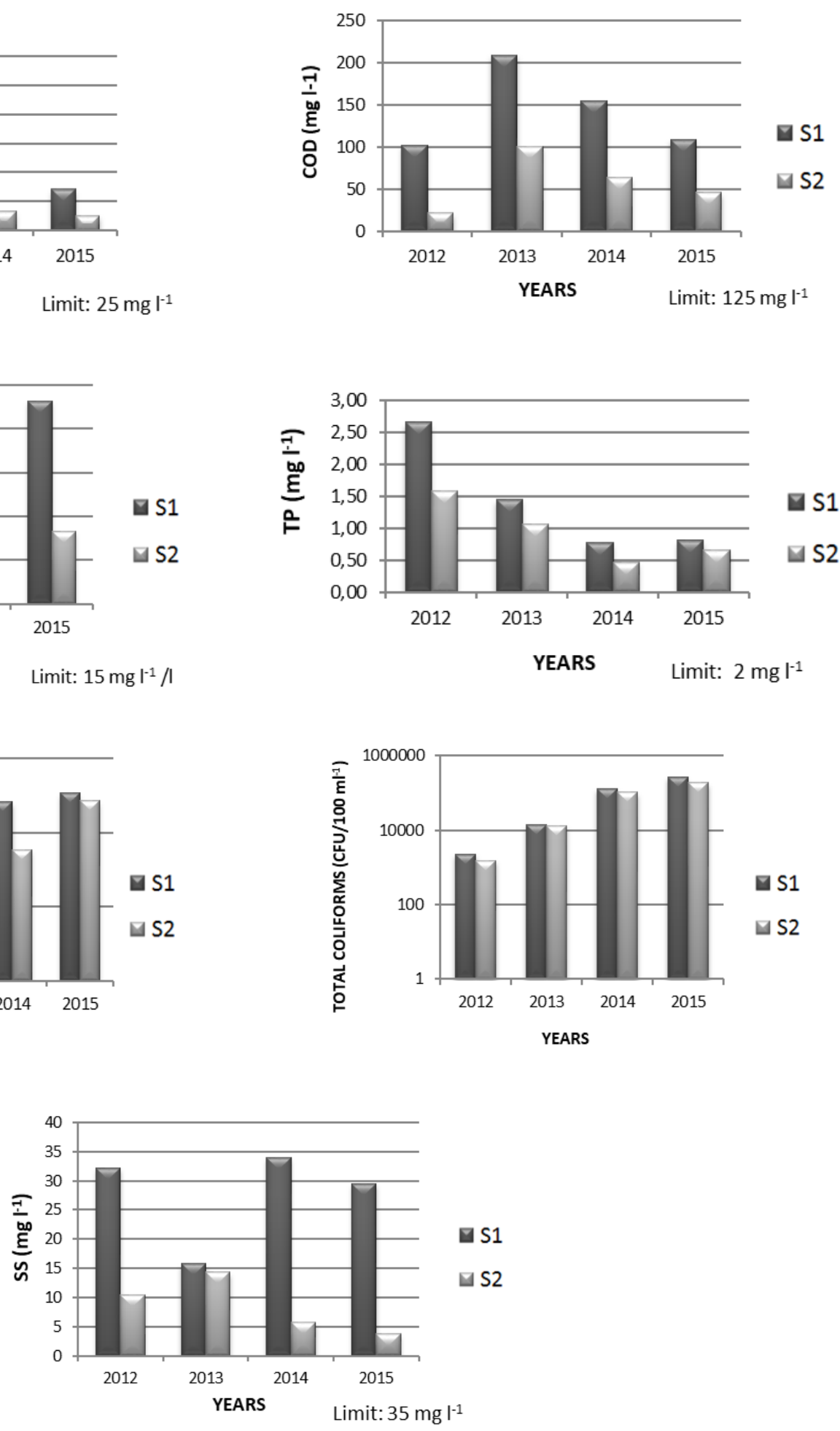

Figure 2. Annual variations in the physico-chemical and bacteriological parameters before and after treatment 
Table 3. Methane emissions from domestic wastewater

\begin{tabular}{|c|c|c|c|c|c|c|c|}
\hline Year & $\begin{array}{l}\text { Income } \\
\text { group }\end{array}$ & $\begin{array}{l}\text { Pop. income } \\
\text { group } \\
\text { fraction (U) } \\
\text { (a) }\end{array}$ & $\begin{array}{l}\text { Fraction of } \\
\text { degree of } \\
\text { utilization }\left(\mathrm{T}_{\mathrm{ij}}\right) \\
\text { (b) }\end{array}$ & $\begin{array}{c}\text { Net methane } \\
\text { emissions }\left(\mathrm{kg} / \mathrm{CH}_{4} / \mathrm{yr}\right) \\
g=\left[\left(a^{*} b^{*} c\right)^{*}(\mathrm{~d}-\mathrm{e})\right]-\mathrm{f}(\mathrm{g})\end{array}$ & $\begin{array}{l}\text { GWP } \\
\text { for } \mathrm{CH}_{4} \\
\text { (h) }\end{array}$ & $\begin{array}{c}\text { Total } \mathrm{CO}_{2} \mathrm{e} \\
\left(\mathrm{kgCO}_{2} \mathrm{e} / \mathrm{yr}\right) \\
\left(\mathrm{i}=\mathrm{g}^{*} \mathrm{~h}\right) \\
\text { (i) }\end{array}$ & $\begin{array}{c}\text { Total } \mathrm{CO}_{2} \mathrm{e} \\
\left(\mathrm{tCO} \mathrm{e}_{2} / \mathrm{yr}\right) \\
\text { (j) }\end{array}$ \\
\hline \multirow{7}{*}{2012} & Rural & 0.32 & 0.58 & \multirow{7}{*}{2994.684} & \multirow{7}{*}{25} & \multirow{7}{*}{74867.1} & \multirow{7}{*}{74.87} \\
\hline & Urban & & & & & & \\
\hline & high & 0.68 & 0.96 & & & & \\
\hline & income & & & & & & \\
\hline & Urban & & & & & & \\
\hline & $\begin{array}{c}\text { low } \\
\text { income }\end{array}$ & 0.00 & NA & & & & \\
\hline & Total & 1 & 0.77 & & & & \\
\hline \multirow{7}{*}{2013} & Rural & 0.32 & 0.58 & \multirow{7}{*}{9959.7498} & \multirow{7}{*}{25} & \multirow{7}{*}{248993.745} & \multirow{7}{*}{248.99} \\
\hline & Urban & & & & & & \\
\hline & high & 0.68 & 0.96 & & & & \\
\hline & income & & & & & & \\
\hline & Urban & & & & & & \\
\hline & $\begin{array}{c}\text { low } \\
\text { income }\end{array}$ & 0.00 & NA & & & & \\
\hline & Total & 1 & 0.77 & & & & \\
\hline \multirow{6}{*}{2014} & Rural & 0.32 & 0.58 & \multirow{6}{*}{3507.2037} & \multirow{6}{*}{25} & \multirow{6}{*}{87680.0925} & \multirow{6}{*}{87.68} \\
\hline & Urban & & & & & & \\
\hline & high & 0.68 & 0.96 & & & & \\
\hline & income & & & & & & \\
\hline & $\begin{array}{l}\text { Urban } \\
\text { low } \\
\text { income }\end{array}$ & 0.00 & NA & & & & \\
\hline & Total & 1 & 0.77 & & & & \\
\hline \multirow{6}{*}{2015} & Rural & 0.32 & 0.58 & \multirow{6}{*}{2736.5184} & \multirow{6}{*}{25} & \multirow{6}{*}{68412.96} & \multirow{6}{*}{68.41} \\
\hline & Urban & & & & & & \\
\hline & high & 0.68 & 0.96 & & & & \\
\hline & income & & & & & & \\
\hline & $\begin{array}{l}\text { Urban } \\
\text { low } \\
\text { income }\end{array}$ & 0.00 & NA & & & & \\
\hline & Total & 1 & 0.77 & & & & \\
\hline
\end{tabular}

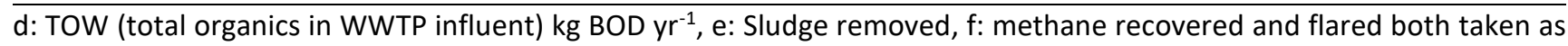
0 .

\subsection{Estimated wastewater treatment plant nitrous} oxide $\left(\mathrm{N}_{2} \mathrm{O}\right)$ emissions

Table 4 gives calculated $\mathrm{N}$ in effluent by using Table 6.11 of IPCC, (2006): $\mathrm{N}_{2} \mathrm{O}$ methodology default data of IPCC, (2006) was used for calculations for estimation of nitrogen in effluent whereas Table 5 estimates emission factor and emissions of indirect $\mathrm{N}_{2} \mathrm{O}$ emissions from wastewater.

\subsection{Estimated wastewater treatment plant indirect emissions}

Indirect GHG emissions from the consumption of electricity at WWTP was calculated by the use of emission factor of $0.91 \mathrm{tCO}_{2} \mathrm{e} \mathrm{Mwh}^{-1}$ and provided in Table 6. Finally, total emissions of full-scale SBR WWTP were given in Table 7.

\section{Conclusions}

One of the aims of the study is to provide scientific data on the impact of wastewater treatment plants on climate change. Other aims are to demonstrate 1) the treatment efficiency of full-scale WWTP; (2) how WWTP influences creek's water quality from 2012 to 2015; (3) how creek influences receiving body's water quality and (4) the potential climate change impact of a SBR treatment system treating domestic wastewater by calculating its GHG emissions.

The findings obtained from measurements and calculations show that the wastewater treatment plant meets the Turkish discharge standards. However, since there is no summer flow before the stream where the treated water is discharged, there is a decrease in the water quality of the final receiving body especially in terms of bacteriological parameters. Between 2012 and 2015 the effect of WWTP on receiving bodies' bacteriological quality was severe but with a newly added UV disinfection unit the problem has already been solved. This research proved that an increase in concentration of pollutants will occur during low flows when point sources dominate. 
The study is also used for estimating energy use and GHG emissions from a SBR WWTP. The annual methane emissions from SBR WWTP ranged from minimum of 68.71 to maximum 248.99 tCO 2 e. Total emissions $\left(\mathrm{CH}_{4}, \mathrm{~N}_{2} \mathrm{O}\right.$ and emission due to electricity usage) from a full-scale SBR wastewater treatment plant (WWTP) were calculated as 144.22 $\mathrm{tCO}_{2} \mathrm{e}, 318.34 \mathrm{tCO}_{2} \mathrm{e}, 474.79 \mathrm{tCO}_{2} \mathrm{e}$ and 996.62 $\mathrm{tCO}_{2} \mathrm{e}$ from 2012 to 2015, respectively.
The reason behind the increase in total emissions is mainly increase in electricity usage which had the highest value in 2015. It would be feasible to capture $\mathrm{CH}_{4}$ produced in the treatment process or used for generation of electricity or used as a fuel at site.

Table 4. Estimation of nitrogen in effluent

\begin{tabular}{|c|c|c|c|c|c|c|c|}
\hline Year & $\begin{array}{l}\text { Pop. } \\
\text { (a) }\end{array}$ & $\begin{array}{l}\text { Annual per capita } \\
\text { protein consumption } \\
\text { (protein) } \\
\text { (kg/person/yr) } \\
\text { (b) }\end{array}$ & $\begin{array}{c}\text { Fraction of } \\
\text { nitrogen in } \\
\text { protein (FNPR) } \\
\text { (kgN/kg protein) } \\
\text { (c) }\end{array}$ & $\begin{array}{l}\text { Fraction of non- } \\
\text { consumption } \\
\text { protein } \\
\text { (Fnon-cons.) } \\
\text { (d) }\end{array}$ & $\begin{array}{c}\text { Fraction of } \\
\text { industrial and and } \\
\text { commercial co- } \\
\text { discharged } \\
\text { protein (Find-com.) } \\
\text { (e) }\end{array}$ & $\begin{array}{l}\text { Nitrogen } \\
\text { removed } \\
\text { with sludge } \\
\left.\text { ( } \mathrm{N}_{\text {sludge }}\right) \\
\text { (f) }\end{array}$ & $\begin{array}{c}\text { Total nitrogen } \\
\text { in effluent } \\
(\mathrm{kgN} / \mathrm{yr}) \\
g=\left(a^{*} \mathrm{~b}^{*} \mathrm{c}^{*} \mathrm{~d}^{*} \mathrm{e}\right)- \\
\mathrm{f} \\
\text { (g) }\end{array}$ \\
\hline 2012-2015 & 4186 & 0.052 & 0.16 & 1.4 & 1.25 & 0 & 60.95 \\
\hline
\end{tabular}

Table 5. Estimation of emission factor and emissions of indirect $\mathrm{N}_{2} \mathrm{O}$ emissions from wastewater

\begin{tabular}{|c|c|c|c|c|c|c|c|c|}
\hline Year & $\begin{array}{l}\text { Nitrogen in } \\
\text { effluent } \\
\text { (kgN/yr) } \\
\text { (a) }\end{array}$ & $\begin{array}{c}\text { Emission } \\
\text { factor } \\
\text { (kg N }{ }_{2} \mathrm{O}- \\
\mathrm{N} / \mathrm{kgN} \text { ) } \\
\text { (b) }\end{array}$ & $\begin{array}{l}\text { Conversion factor } \\
\text { of } \mathrm{kg} \mathrm{N} \mathrm{N}_{2} \mathrm{O}-\mathrm{N} \text { into } \\
\mathrm{kg} \mathrm{N} \mathrm{N}_{2} \mathrm{O}-\mathrm{N} \\
44 / 28 \text { (c) }\end{array}$ & $\begin{array}{l}\text { Emission } \\
\text { from } \\
\text { wastewater } \\
\text { plants } \\
\text { (default as } \\
\text { zero) } \\
\text { (d) }\end{array}$ & $\begin{array}{l}\text { Total } \mathrm{N}_{2} \mathrm{O} \\
\text { emissions } / \mathrm{yr} \\
\text { (e) }\end{array}$ & $\begin{array}{l}\text { GWP for } \\
\mathrm{N}_{2} \mathrm{O} \\
\text { (f) }\end{array}$ & $\begin{array}{c}\text { Total } \mathrm{CO}_{2} \mathrm{e} \\
\left(\mathrm{kg} \mathrm{CO} \mathrm{CO}_{2} / \mathrm{yr}\right) \\
\text { (g) }\end{array}$ & $\begin{array}{c}\text { Total } \mathrm{CO}_{2} \mathrm{e} \\
\left.\text { (t CO } \mathrm{CO}_{2 \mathrm{e}} / \mathrm{yr}\right) \\
\text { (h) }\end{array}$ \\
\hline $2012-2015$ & 60.95 & 0.005 & 1.57 & 0 & 0.478 & 298 & 142.58 & 0.143 \\
\hline
\end{tabular}

Table 6. Electricity consumption of the wastewater treatment plant

\begin{tabular}{cccc}
\hline Year & Total Mwh used yearly & $\begin{array}{c}\text { Emission factor } \mathrm{tCO}_{2} \mathrm{e} \mathrm{Mwh}^{-1} \\
\text { (b) }\end{array}$ & $\begin{array}{c}\text { Emission } \mathrm{tCO}_{2} \mathrm{e} \\
\text { (c=a*b) }\end{array}$ \\
\hline 2012 & 76.2 & 0.91 & 69.34 \\
\hline 2013 & 76.2 & 0.91 & 69.34 \\
\hline 2014 & 425 & 0.91 & 387.1 \\
\hline 2015 & 1020 & 0.91 & 928.2 \\
\hline
\end{tabular}

Table 7. Total emissions of the wastewater treatment plant

\begin{tabular}{ccccc}
\hline Year & $\begin{array}{c}\mathrm{CH}_{4} \\
\left(\mathrm{tCO}_{2} \mathrm{e}\right)\end{array}$ & $\begin{array}{c}\mathrm{N}_{2} \mathrm{O} \\
\left(\mathrm{tCO}{ }_{2} \mathrm{e}\right)\end{array}$ & $\begin{array}{c}\text { Electricity usage } \\
\mathrm{tCO}_{2} \mathrm{Mwh}^{-1}\end{array}$ & $\begin{array}{c}\text { TOTAL } \\
(\mathrm{tCO}\end{array}$ \\
\hline 2012 & 74.87 & 0.0143 & 69.34 & $\mathbf{1 4 4 . 2 2}$ \\
\hline 2013 & 248.99 & 0.0143 & 69.34 & $\mathbf{3 1 8 . 3 4}$ \\
\hline 2014 & 87.68 & 0.0143 & 387.1 & $\mathbf{4 7 4 . 7 9}$ \\
\hline 2015 & 68.41 & 0.0143 & 928.2 & $\mathbf{9 9 6 . 6 2}$ \\
\hline
\end{tabular}

\section{Acknowledgement}

The author is grateful to ÇINAR Mühendislik Müşavirlik ve Proje Hizmetleri, ALKA İnşaat Çevre San. Tic. Ltd. Şti and DOKAY Mühendislik ve Danışmanlık Ltd. Şti. for providing the wastewater quality data used in this study.

\section{Disclaimer}

Any opinions, findings, conclusions, or recommendations expressed herein are those of the author and do not necessarily reflect the view of The Authority for the Protection of Special Areas.

\section{References}

BWQR. (2004), Bathing Water Quality Regulation (in Turkish), prepared by Ministry of Environment and Forest, Official Journal No: 26048.

Bousquet P., Ciais P., Miller J.B., Dlugokencky E.J., Hauglustaine D.A., Prigent C., Van der Werf G.R., Peylin P., Brunke E.-G. and Carouge C. (2006), Contribution of anthropogenic and natural sources to atmospheric methane variability, Nature, 443, 439-443.

EPASA. (2012), (2013), (2014) and (2015), "Project of Monitoring of water quality in Special Environmental Protection Areas". Technical Report prepared by ÇINAR Mühendislik Müşavirlik ve Proje Hizmetleri,, ALKA İnşaat Çevre San. Tic. Ltd. Şti and DOKAY Mühendislik ve Danışmanlık Ltd. Şti. to the Environmental Protection Agency for Special Areas (in Turkish).

Law Y.Y., Ye L., Pan Y.T. and Yuan Z.G.(2012), Nitrous oxide emissions from wastewater treatment processes, Phil. Trans. R. Soc. B., 367, 1265-1277.

IPCC. (2006), Guidelines for National Greenhouse Gas Inventories Chapter 6: Wastewater Treatment and Discharge, 6.1-6.28.

IPCC. (2007), Summary for Policymakers. In: Climate Change 2007: Mitigation. In: Metz, B., Davidson, O.R., Bosch, P.R., Dave, R., Meyer, L.A. (Eds.), Contribution of Working Group III to the Fourth Assessment Report of the Intergovernmental Panel on 
Climate Change, Cambridge University Press, Cambridge, United Kingdom and New York, NY, USA.

Itokawa H., Hanaki K. and Matsuo T. (2001), Nitrous oxide production in high-loading biological nitrogen removal process under low COD/N ratio condition, Water Res., 35, 657-664.

Ravishankara A.R., Daniel J.S. and Portmann R.W. (2009), Nitrous oxide $\left(\mathrm{N}_{2} \mathrm{O}\right)$ : the dominant ozone-depleting substance emitted in the 21st century, Science, 326, 123-125.

TWPCR. (2004), Water Pollution Control Regulation (in Turkish), prepared by Ministry of Environment and Forest, Official Journal, 25(687), 18-76.

UWWTD, (2006). Urban Wastewater Treatment Directive (in Turkish), prepared by Ministry of Environment and Forest, Official Journal No: 26047.

Wang J., Zhang J., Xieh Qi P., Ren Y. and Hua Z. (2011), Methane emissions from a full-scale $A / A / O$ wastewater treatment plant, Bioresource Technology, 102, 5479-5485 